\title{
THE DISCURSIVE CONSTRUCTION OF COLLECTIVE NARRATIVES ON PORTUguese NATIONAL IDENTITY: HOMOGENEITY OR DIVERSITY?
}

\author{
Filipa Perdigão Ribeiro
}

\begin{abstract}
Mainstream conceptions of the "authentic" or "real" Portugal are now so naturalized in national discourse that many of the socio-historical contexts of their discursive construction have been erased from people's collective memory (-ies). This paper presents an overview of the prominent collective narratives and memories in the Portuguese context, highlighting salient historical events that shaped them, such as the 1974 revolution which was a watershed moment from which all current narratives on national identity construct their major reference. It briefly covers 19th century historiography, the Estado Novo's concept of Portugal's "mission in the colonies", the revolution's ideological break with the old regime, and the major myths of homogeneity and self-stereotyping. Thus, contemporary discourses on Portuguese national identity are considered in the light of social memory and diachronic change.
\end{abstract}

KEYWORDS

Portuguese national identity; collective narratives; discourses; 1974 revolution; banal nationalism

\section{A CONSTRUÇÃO DISCURSIVA DE NARRATIVAS COLETIVAS DA IDENTIDADE NACIONAL PORTUGUESA: HOMOGENEIDADE OU DIVERSIDADE?}

\begin{abstract}
RESUMO
As conceções dominantes do Portugal "autêntico" ou "real" estão agora tão naturalizadas no discurso nacional que muitos dos contextos socio-históricos da sua construção discursiva foram apagados da memória coletiva das pessoas. Este artigo apresenta uma visão geral das narrativas e memórias coletivas mais proeminentes no contexto português, destacando os eventos históricos que as moldaram, como por exemplo a Revolução de 1974, a partir da qual todas as narrativas atuais sobre identidade nacional construíram as suas principais referências. Este texto refere brevemente a historiografia do século XIX, a conceptualização do Estado Novo sobre a "missão nas colónias" de Portugal, a rutura ideológica da Revolução com o antigo regime e os principais mitos de homogeneidade e estereótipos. Deste modo, os discursos contemporâneos sobre a identidade nacional portuguesa são considerados à luz da memória social e da mudança diacrónica.
\end{abstract}




\section{INTRODUCTION}

Portugal, through the National Museum of Antique Art, presents its role as both producer and product of good practices of global communication, (...) [which] were accomplished from Europe out into the World and from the World back to Europe, to which the Portuguese have always brought back, from the 15th century until now, the primordial richness that is its immense human diversity.

This excerpt, taken from the introductory text to the international exhibition Encompassing the globe: Portugal and the world in the $16^{\text {th }}$ and $17^{\text {th }}$ centuries ( 16 )uly-11 October 2009), embodies some of the main themes of contemporary Portuguese national identity: the nation as the mediator "by its pioneering navigation of the seas" between "us, the Europeans" and "them, the rest of the world"; the nation as the guardian of "human diversity", or in modern terms, of "multiculturalism and tolerance"; the nation as the mediator that "offered new worlds to the world". It summarises the prominence of a deep hegemonic cultural, historical and essentialist identity narrative that permeates most discourse on Portuguese national identity'. In this light, we are led to ask how these myths of homogeneity surfaced. Billig (1995) has argued that nationalism is too easily discarded as something extreme and irrational. Therefore, the temptation to locate nationalist discourse within the sort of vocabulary which "we" educated citizens do not use is great. However, in an opinion article published on 26 March 2008, the Portuguese poet and politician, Manuel Alegre, declared, in relation to the Orthographic Agreement of 1990: "what is at stake is an issue of national identity". In this context, the Agreement was described, amongst other things, as "an attack on our language", "a disrespect of diversity and linguistic richness" and "a historical error" (Carita, 2008, p. 16). Amongst the younger generation, opinions do not differ. Findings from a survey applied to 198 university students reported that $70,7 \%$ rejected the agreement in order "to protect Portuguese cultural identity and preserve the cultural heritage of Portugal's leading role during the period of empire" (Carvalho \& Cabecinhas, 2013, p. 88). These examples illustrate how the issue of national identity is often surfacing in Portuguese public life, whether it be based on political, economic and social, or, in this particular case, linguistic reasons.

Within the main theories concerning the "creation of the nation", the focus of this paper is primarily on the $19^{\text {th }}$ and $20^{\text {th }}$ centuries, when most debates questioning national identity gained prominence, highlighting major tensions and upheavals Portugal has encountered when dealing with the "other". Additionally, in recent decades, Portugal has been subjected to various historical and social processes. In April 2004, the revolution commemorated its $30^{\text {th }}$ anniversary and a number of the country's intellectuals and opinion makers were ready to initiate a debate on the past three decades. The revolution

\footnotetext{
'Another recent example of the essentialist identity narrative is the Discourse of Inauguration by the current Portuguese President, Marcelo Rebelo de Sousa, in which he declared: "Matrix values of the Constitution are likewise those of national identity, rooted in our land and our sea, but of universal vocation - a platform that we build between continents and, above all, between cultures and civilizations". Inaugural address of the President of the Republic, Marcelo Rebelo de Sousa in Parliament, 9 March 2016, retrieved from http://www.presidencia.pt/?idc=22\&idi=103410
} 
had ended Portugal's political dominance over its former African colonies and impacted on the long-standing debate on "Portugal's symbolic role" and on the mythical interpretation of its national identity. Joining the European Union in 1986 and the increasing globalization of the economy led to an urgent reflection on the consequences of the revolution and to the on-going debate on national identity. Moreover, the increasing numbers of labour migrants arriving in Portugal from the 1980 s onwards ${ }^{2}$ has inevitably put into question the idea of "perfectly assimilated citizens" and has reshaped national institutions and group-related rights, with implications for the nature and practices of national identity (Biles \& Spoonley 2007, p. 194). Interestingly, Portugal's nation-building, historically dating back to as early as the 13th century presents an original case as it deviates from some of the major theories that ascribe the creation of nationalism to the modern state (Anderson 1983/2006, p. 4; Gellner, 1983/2006; see Almeida, 2004, on the originality of Portugal's case).

The analysis here is guided by four major factors that have shaped the discursive construction of the country's national identity, the first of which relating to its size. As a rather small and modestly populated country, with an overpowering Spain as its only neighbour, the relationship between the two countries has shaped most debates on the topic ${ }^{3}$. The second element relates to the idea of the "glorious overseas empire", whose administration was undertaken by the Portuguese state from the early $15^{\text {th }}$ century to the mid-20 $0^{\text {th }}$ century4. In turn, these "imaginary" / imagined" and real relationships overseas shaped the country's perception of its relationship with Europe, perceived and (discursively) constructed as a rather abstract integral whole (i.e. countries are not individualized). The dictatorship and the colonial war in Africa, which lasted thirteen years, both during the $20^{\text {th }}$ century, constitute the third and fourth factors to have an impact on Portugal's self-image, public discourses and narratives of self-representation. These factors are further explored in the following sections.

This article discusses salient collective narratives and memories within the Portuguese context, linking them to the historical events that shaped them. It is designed to provide a concise overview of some of the wider socio-political and historical dimensions relating to questions of identity-construction and of "belonging" in Portugal from a macro viewpoint, drawing from research in critical discourse studies, history, sociology and anthropology. The aim is to trace the major public discourse constructions on Portuguese national identity that frame national contemporary discourses on the subject and to understand how state authorities, and scholarly and political elites, through the mediation of the public sphere - media, school, public speeches, historical accounts, etc. -, have played a major role in shaping recent collective memories and narratives.

\footnotetext{
${ }^{2}$ See Vieira and Trindade (2008) and Peixoto (2014) for an overall perspective of recent migration to Portugal.

${ }^{3}$ As early as the $14^{\text {th }}$ century, a growing sense of hatred against Castile and León (two of the several former kingdoms which became Spain) developed amongst the Portuguese population. Various authors, including Saraiva and Lopes (1987) have highlighted how these feelings have led to regular outbursts across the centuries, namely at times when Portugal's independence was at stake.

4 The nation's administrative power extended from Portugal itself to India (Goa, Damao and Diu), China (Macau), East Asia (East-Timor), Africa (Mozambique, Angola, Guinea-Bissau, Cape Verde and S. Tomé and Príncipe) and Latin America (Brazil).
} 
This paper begins by covering the main narratives of the latter in 19th century historiography, when the first public debates on the issue of "national identity" surfaced. Secondly, prominent narratives on "Portugal's mission in the world" imposed on the population during the time of the dictatorship will be described. The colonial war, which took place in the last thirteen years of the Estado Novo and its major role in the construction of national identity narratives is also addressed. Thirdly, the focus will be on how the $25^{\text {th }}$ of April 1974 revolution and its aftermath shaped the narratives and collective memories on the recent past and how Portugal's elites felt a strong need to "rethink Portugal", by resuming the old $19^{\text {th }}$ century debate. Advocated by many literary authors and historians, this debate favoured the European project to the detriment of the "imperial project". Then follows a summary of the major claims on the dominant narratives of Portuguese national identity as put forward by historians, sociologists, philosophers and literary authors, and how these discourses construct "the other". The final section focuses on the construction of discourses on Portugal's relationship with three specific parties: Spain, the various "newcomers" and Europe.

\section{ASSUMPTIONS UNDERLYING THE DISCURSIVE CONSTRUCTION OF NATIONS AND NATIONAI IDENTITIES}

The approach to national identity and nationhood followed here draws from several assumptions. To begin with, nations are to be understood as mental constructs, as "imagined political communities" (Anderson, 1983/2006, p. 6). "They are represented in the minds and memories of the nationalized subjects as sovereign and limited political units" (De Cillia, Reisigl \& Wodak, 1999, p. 153) through discourses (language and other semiotic systems) produced, reproduced, transformed and/or destructed. The rightwing Portuguese dictator Salazar understood clearly how this representation worked and played with the idea in relation to the Portuguese colonial empire. Nowadays, this representation still plays a major role in the discursive construction of Portuguese national identity. Next, national identity can be regarded as a sort of "habitus" (drawing on Bourdieu's notion), i.e. "a complex of common ideas, concepts or perception schemes of related emotional attitudes intersubjectively shared within a specific group of persons, all of which are internalized through 'national' socialization" (De Cillia et al., 1999, p. 153).

In the case of the Portuguese nation, the ideas and schemata in question relate to the idea of Portuguese character traits that set its nationals apart from other peoples including stereotypical notions that distinguish "them" from "us", a "common national history, culture, present and future", as well as a "specific national territory". These behavioural dispositions include both solidarity with one's own national group, as well as the readiness to exclude others from this constructed collective.

The next assumption, which follows from the last, regards the "discursive construction of nations and national identities [as running] hand in hand with the construction of difference/distinctiveness and uniqueness" (De Cillia et al., 1999, p. 153). The moment it is "elevated to an imaginary collective level, both the construction of sameness and 
the construction of difference violate pluralistic and democratic variety and multiplicity by group-internal homogenization" (De Cillia et al., 1999, p. 153). This last point is highly visible in the persistent group internal homogenization conveyed in general by the media output or by presidential speeches 5 . Even so, national identity is not fixed in an essentialized sense, since there will invariably be competing conceptions, histories and stereotypes (Billig, 2009, p. 348). Also, different identities are discursively constructed according to context, e.g. audiences to which narratives or speeches or written genres are addressed, the situational setting of the discursive act and the topic being discussed (De Cillia et al., 1999, p. 153; Wodak, 2006, p. 106). Lastly, contemporary life is daily infused with nationalist assumptions and symbols, which often pass unnoticed. That is to say, "the complex of beliefs, assumptions, habits, representations and practices" are reproduced in a "banally mundane way", endemically (Billig, 1995, p. 6).

\section{RACE AND NATIONHOOD}

Portugal is the oldest European nation-state, its borders dating back to the $12^{\text {th }}$ century, when the would-be king, Afonso Henriques, fought in battle his own cousin, the Alfonso VII of León. Afonso Henriques proceeded by crowning himself rex Portugalensis (King of Portugal) and adopting an expansionist policy against the Moors and the Spaniards. The country's foundation narrative is well known by Portuguese nationals who have been schooled in the country. It is presented here on the grounds of its paradigmatic value in terms of the generally accepted essentialist view of Portuguese national identity. To implement this view, the Estado Novo controlled the History curriculum imposing official narratives and enhancing the relationship between History and nationalist projects, such as the Romantic versions of the Portuguese nation framed during the $19^{\text {th }}$ century (Torgal, 1989). In fact, this account - originally shaped by 19th century historiography - of the foundation narrative was seen as a definite separation from what would later become Spain and has been discursively used to distance the country from its territorial neighbour.

During the $19^{\text {th }}$ century, as everywhere else in Europe, issues of nationalism dominated the Portuguese public sphere. Theories explaining the genesis of the nation became common knowledge (Sobral, 2004, p. 257). The historian Alexandre Herculano (1846/1980-81) argued that the Portuguese nation was a political product, this being a result of its formation at the hands of barons from the Northwest part of the Iberian Peninsula. Another prominent 19th century historian, Oliveira Martins (1879), following on Herculano's theory, added that there were traits of Celtic origin in the Portuguese character. Oliveira Martins (1879, p. 29) believed in an Iberian civilization, in a "peninsular character [that was the] fundamental trait of the race". Thus, the ethnic/racial argument became widespread during the 1870 s and 1880 s. The representation of the country's history, in parallel with Spain, comprised two main stages: one of grandeur, which reached its peak during the $16^{\text {th }}$ century overseas empires; and the following one of decadence

\footnotetext{
${ }^{5}$ See footnote 1.
} 
which lasted until the $19^{\text {th }}$ century. Teófilo Braga, also a Portuguese historian, insisted on the ethnic approach to Portuguese nationality; he argued for a racial distinctiveness from Spain, including the Arabian influence during their seven-century long dominance of the southern regions of Portugal (Braga, 1885, 1894).

As a result, the racial factor was perceived as a prominent element in social organization. By the second half of the 19th century, the interpretation of nationalism based on race (even if it was a combination of diverse peoples) contributed to a sense of community, drawing on the false sense of a unique origin and a common destiny. During this period and extending to the first decades of the $20^{\text {th }}$ century, successive political and economic national crises, the country's ever decreasing political role in Europe, and the increasing population migration to Brazil, instilled the idea that the "historical essence of the first centuries of the Portuguese state" (Sobral, 2004, p. 266) had to be recaptured.

At a later stage, other authors suggested that there was a continuity or homogeneity between the Lusitan people and the Portuguese (Correia, 1919), or between various ethnic groups, including Arabs, Jews and Blacks (Vasconcellos, 1940-1941), claiming the presence of common character traits. After World War II, school syllabuses, despite being embedded in the fascist ideology of António de Oliveira Salazar's ruling, stressed the multiple ethnic contributions to the peopling of the Iberian Peninsula, never referring to words such as "Arian" or "Semitic" because of their obvious negative stigma. Under Salazar's nationalist ideology, the emphasis placed on the multiple ethnic origins of the Lusitan people was expanded into Gilberto Freyre's concept of Lusotropicalism "which embodied the myth of a multiracial harmonious Portuguese Empire" (Cusack, 2005 , p. 601). As such, the Portuguese "had the objective or pedagogical aim of lessening all racist theories (...) the ideal of a pure race never limited Portuguese endeavours" (Freyre, 1942, p. 48) ${ }^{6}$. This concept, seized by Salazar's ideology - because it provided a repertoire for the regime as it sought to out manoeuvre increasingly "vociferous criticism from anti-imperialists at the United Nations and in other international fora" (Sidaway \& Power, 2005, p. 542) - projected "Portuguese independence over the centuries based on the denial of any ethic purism" and over "the conscience of the needs, aspirations and common interests of ethnically heterogeneous elements" (Freyre, 1942, p. 25). Even though it has been modernized, this multi-cultural image of the Portuguese prevails in terms of discursive construction.

\section{The Estado Novo AND THE PORTUGALIDADE}

The right-wing dictator Salazar stepped into political power as the Minister of Finance in 1928 and initiated what was officialised as the Estado Novo in the 1933 Constitution. Eventually, Salazar ruled the country almost single-handedly as Prime Minister

\footnotetext{
${ }^{6}$ The initial stages of the concept which would become "lusotropicalism" was first introduced by the Brazilian anthropologist Gilberto Freyre in Casa-Grande o Senzala (1933); the expressions "luso-tropical modern culture" and "tropicalism" were first used during the author's lecturers in Goa (1951) and Coimbra (1952) (Castelo, 1999, p. 33, 2011, p. 267). It encompasses the direct, living experiential knowledge of the tropics, both in the East and in Africa or America that gave way to a new type of Lusotropical civilization, entailing a unique symbiotic character of union of European with Tropical.
} 
from 1932 until 1968. The dictatorial regime lasted until the $25^{\text {th }}$ April revolution in 1974, then under the command of its only other Prime Minister, Marcello Caetano, who succeeded Salazar in 1968. At the time, Portugal had the longest-running fascist regime in the world. Regrettably, the Salazar/Caetano government had spanned through inter-war years, World War II, and the post-war period.

The Estado Novo reinforced nationalist values on the Portuguese population. The education system was tailored toward the glorification of the Portuguese nation and its five-century-old overseas territories (the Ultramar).

From the 1930s onwards, the Estado Novo assumed the "historical mission of colonizing and civilizing the native populations" (Colonial Act, 1930, article 2). This would be the "mission and burden of the Portuguese people" (Rosas, 2001, p. 1034) and the organic essence of the Portuguese nation, which, in turn, justified and legitimized the right to occupy, possess and colonize the overseas territories These unalienable rights over overseas territories were grounded on the maintenance of national independence, perceived and discursively construed to be constantly under threat from Spain. At the same time, the large dimension of the Colonial Empire over-compensated for a smallsized continental Portugal (Rosas, 2001).

In the pursuit of its aims, the Estado Novo attempted to establish a mythical ideal of the "Portuguese essence" (Rosas, 2001, p. 1034). Salazar was, however, concerned mainly with the elites. He believed that the future of the nation and the regime depended, above all, on the educated elites, who would perpetuate the "true national interest" (Rosas, 2001, p. 1038).

This being the case, the strong uphold of the dictatorship was an ideology built on the concept of Portugalidade (or Portugueseness) and overseas expansionism, as well as on the idea of family and the Catholic religion. Therefore, "losing Africa" in the 1970s, the last symbolic and political possession of the overseas empire, was, and is still to some sectors of the population, the great loss of a nation that remained unable to find itself (Ferreira, 1993, p. 173). Many Portuguese viewed the overseas territories and Portugal as eternally linked through the Portuguese language and culture ${ }^{7}$. However, except for the religious sector (which had the Church organization as main support), the pyramidal authoritarian approach to the dissemination of these ideologies, was never completely embedded in the people's "flagging-of-the-nation" (Billig, 1995). In fact, large sectors of the population increasingly resented the colonies and, from 1961 onwards, when the colonial war began in Angola, the war effort. The latter involved a significant drain on the national budget and, more importantly, demanded high numbers of young male recruits $^{8}$. Another factor of resentment towards the African colonies was the implication of a "spoiled Portugueseness", effused by the Portuguese who had migrated to Africa. It was perceived that these migrants labelled as "os retornados" (literally, the come-backs)

\footnotetext{
7 On a survey from 2001 the Portuguese declared that the top four reasons for feeling national pride were the Discoveries, the $25^{\text {th }}$ April revolution, the Portuguese language across the world, and the historic links with other peoples (Almeida, 2004).

${ }^{8}$ One million people are estimated to have been involved (including civilians, families, etc.) in the war effort, travelling to Africa at some point in the 1961-1974 period.
} 
held lifestyle "practices that were cast as morally suspect by kin and community members who had remained behind in Portugal" (Lubkemann, 2002, p. 189). As a result, after the 1974 Revolution, the so called retornados were strongly stigmatized by the population who had remained in Portugal9, in stark contrast with the Portuguese who had migrated to other destinations, such as France, Luxembourg or Germany or the America continent (Lubkemann, 2002).

Hence, the Estado Novo claimed and disseminated the image of a "greater Portugal", a necessary representation to uphold Portugal's independence against "the other". The population in general, mostly illiterate, assimilated these representations while simultaneously resenting the de facto nation for economic, social and emotional reasons, since "their boys" had to navigate overseas to fight in the colonial wars. In parallel, small minorities of educated elites either upheld the state's ideology or rebelled against it - insofar as possible given the censorship and the active role of the political police, known by the acronym PIDE - questioning the Portuguese so called "mission" overseas. This ambivalence toward the hegemonic idea of nation would persist during the years immediately after the revolution, and even further into the future, shaping discourses on national identity and the initial rejection of anything related to patriotism or national symbols, since these were perceived as authoritarian, anti-democratic and directed against freedom ${ }^{10}$.

\section{The $25^{\mathrm{TH}}$ Of April Revolution AND The (BRIEF) REJECTION OF NATIONAL SYMbols}

The revolution introduced a major break with the authoritarian values, beliefs and ideologies of the previous regime (Barreto, 1995, 2000; Cabral, 1999). During the inevitable post-revolutionary enthusiasm, the Portuguese population felt that the formerly enforced cultural paradigms had collapsed, namely the insistence on maintaining the private sphere "secret" and the public sphere" under the scrutiny of censorship. In the revolution aftermath, prevalent social ideologies promoted the collective over the individual. Almeida (2004, p. 3), for instance, suggests that, in terms of collective memory, the "revolution inaugurated the largest collective utopia of the Portuguese". However, the author adds, during the turmoil people forgot that the past is part of national identity. In fact, for a brief period, post-revolutionary Portugal tried to reject its recent past and with it, its collective history, precisely because the Estado Novo's ideological policy had appropriated, reframed and incorporated it.

This brief interruption of the dominant/hegemonic public discourses was followed in the 1980 s by an increasing distrust in the social ideologies flagged by left-wing

\footnotetext{
${ }_{9}^{9}$ See, for instance, the web log post of Passos (2016, January 6) in which he describes this traumatic experience.

${ }^{10}$ In fact, the population in general appeared to have only made peace with the country's flag during the Expo World Exhibition in 1998 and the European Football Championship in 2004, events in which the flag was fully and proudly exhibited. In 2000, aiming at increasing national awareness, the Portuguese government distributed a so-called patriotic kit to primary school children and encouraged the children to sing the national anthem (Almeida, 2004).

"According to Jürgen Habermas' traditional model (1962/1989) the mediating element of the social system is the public sphere, comprising major political and cultural institutions and the press. Social agents either reproduce or contest the institutional structure, therefore enabling a potential for reflexivity, both by individuals and collectivities.
} 
partisans. The political focus on culture as heritage, Portugueseness and national identity returned. Being "national" became a unifying value within the growing preoccupation over the image of the country and its European recognition, together with a lack of debate over what would be salient in terms of cultural policies (Reis, 1993, p. 473).

From an analytical perspective, during the eighties and nineties, Portuguese academics felt the need to revisit the historical past anew based on valid modern scientific premises. Scholars were interested in interpreting Portugal's identity (and politics) in the light of international scenarios: Europe, the United States, international North-South relationships and the former Portuguese colonies in Africa. Researchers became increasingly aware that to understand Portugal they had to look at the "other" (Barreto, 1994, p. 1064). Since then, sociologists have argued that the phenomena considered to be permanent by the Estado Novo and to a certain extent still engrained in collective discourses on national identity, are in fact, constantly mutating. Examples of these would be Portuguese culture, language, ethnicity, religion and certain traditions (Barreto, 2000, p. 38).

\section{Dominant NaRRatives on Portuguese National IDENTITY - MYTHS OF HOMOgeneity AND SELF-STEREOTYPING}

The dictatorship, the colonial war and the revolution were traumatic events ${ }^{12}$, which have been shaping public discourses on national identity, reframing collective memories and in-group and out-group boundaries in a very particular self-reflective form. The last four decades have witnessed the ongoing contest within the Portuguese public sphere for the one and only narrative, which should be hegemonic. Various groups - elites, political parties, academics - compete over the interpretation(s) of the Estado Novo's ideology and its discursive construction of national identity; moreover, in a seemingly paradoxical way, both left-wing and right-wing partisans contend over who understands and narrates more convincingly "the imaginary past" which remains prominent in the construction of Portuguese national identity. This past tends to circle back to the sixteenth century, considered as the peak of Portugal's national and collective history, the same historical period Salazar elected to symbolize the greater Portugueseness. It is indeed remarkable how hegemonic the constitutive myths became, especially in view of the fact that, as stated above, the dictatorship machine reframed these historical events to serve its political agenda. One would have expected the replacement of these narratives based on the heroes from the sixteenth century maritime discoveries with different ones as a reaction to the Estado Novo's ideology.

In recent years, Portuguese national identity has been the concern of several academic fields such as history (Mattoso, 1998), philosophy (Almeida, 2002, 1995; Cruzeiro, 2014; Gil, 2004; Lourenço, 1988, 1997), sociology (Barreto, 2000, 1995; Conde, 1990;

\footnotetext{
${ }^{12}$ On various levels, the revolution and the following decade were traumatic for large segments of the Portuguese population. Private businesses were nationalized, agricultural land was taken over by rural labourers, governments were shortlived, inflation skyrocketed; the state was on the verge of bankruptcy. In a very short period of time (1974-1975) the country had to welcome, give shelter to, and find jobs for more than 600,000 people, dislocated from the five, newly independent, former Portuguese colonies in Africa.
} 
Ribeiro, 2003; Santos 1993; Sobral, 2004, 2003), discourse analysis (Ribeiro, 2011), to name a few. In both literary and critical works, the issue has been discussed and readings or hypotheses have been offered on what Portuguese national identity is and how collective memories were and are shaped'3.

It is possible to pinpoint two main arguments in relation to Portuguese national identity. On the one hand, largely grounded on the $20^{\text {th }}$ century context, more specifically on the Salazarist dictatorship, there is the discursive construction of a homogeneous and united identity. On the other hand, these claims are rebutted by academics such as Mattoso (1998) and Sobral (2003), whose arguments are based on the claim that the "Portuguese nation has been built on various elements since the Middle Ages" (Mattoso, 1998, p. 98). Accordingly, during the $13^{\text {th }}$ and $14^{\text {th }}$ century, the state's strong nuclear role (and the elite's - aristocracy and clergy - dissemination of the representations of the nation amongst the population) was crucial in the process of bringing together various ethnic groups under the idea of a collective nation.

Anderson (1983/2006, p. 11) dates the emergence of the idea of nation (as a cultural artefact) from the late 18th century (the age of Enlightenment and Revolution) associated with the birth rise of the newspaper that enabled people from afar to imagine the community "observing exact replicas of their own paper" (Anderson, 1983/2006, p. 35) at the same time.

Portugal's originality, however, lies in the fact that the historical process of gathering its people together (i.e. creating the "imagined community") under the scope of one nation began much earlier. The idea of a Portuguese cultural wholeness, together with a fundamental linguistic unity singles out the country from most other European nation creation process, where these elements were not as strong or did not even coincide with the nation-state.

After extensive post-revolution critical investment from the social sciences - focused on comparing Portugal to Europe on several accounts: historical phenomena; geographical location; distinctions between an underdeveloped economic production and the recent overdeveloped mass consumption; and the significant educational, cultural and economic gap between the cultural elites and the remainder of the population (Cabral, 1992; Santos, 1993) - Portugal is believed to constitute a solid unity, while also being recognized for accepting diversity on the grounds of its multicultural origin.

This last argument has fuelled the most common or traditional discourses on Portuguese identity, which invoke the country's exceptional character (Medeiros, 1996, p. 12). This so-called uniqueness is to be found both in the country's national unity, territorially and linguistically, as well as in the construction of the "imagined community" at the core of the myth of the country's full-hearted embrace of diversity. This myth originates in the historical fact that, until the 16th century, the Portuguese were the intrinsic product of ethnic and cultural miscegenation. Conversely, Barreto (1995, p. 842) has claimed that Portugal is "surprisingly [formed of] one territory, one people, one nation, one language,

${ }^{13}$ See in this regard the journal Comunicação e Sociedade, $(29,2016)$ dedicated to the topic of Colonial Imaginaries: propaganda, militancy and "resistance" in the cinema. 
one border, one religion, forged centuries ago, kept during centuries" and that "these realities belonged to a rare case of unity in history" (see also Barreto \& Pontes, 2007).

In an insightful paper, Almeida (2002) divides the contenders of the national identity debate into three main groups. He identifies the first group as the traditionalists, who adopt essentialist positions that lack any kind of scientific rigor. The second group is constituted by social scientists, whose methodology is a combination of empirical verification and conceptual rigor based on data, statistics and quantitative approaches to the issue. Lastly, the third group comprises an understanding of both history and Humanities and an appraisal of "the transformation of underlying structures that tie together the elements of a cultural group and an awareness of tradition and the symbolic importance of identity-forming factors" (Almeida, 2002, p. 6). Nonetheless, the author reinforces that "very few, if any, scholars make claim that Portugal possesses a cultural individuality that radically sets it apart" (Almeida, 2002, p. 9).

As Stråth and Wodak (2009, p. 16) perceptively point out, "the crisis concept and contentious value mobilization (right/wrong, good/bad society, friend/enemy) [are] reflected and reinforced in the public sphere through appeals to specific values". Accordingly, politicians use the argument of the "identity crisis" when it serves their agenda: for instance, a Portuguese phone-in radio-programme broadcasted in July 2006 branded the theme topic "Is national identity in crisis?" (see Ribeiro, 2009). This topic was branded even though Lourenço $(1988$, p. 19) has repeatedly stated that "Portugal, of yesterday and even more so of today, never had, nor has, problems of identity".

To conclude this brief overview, both discourses on national identity - the one claiming homogeneity and the one arguing for an exceptional understanding of diversity - are used today by the dominant political power to explore opportunistically the nation's relationship with the international community, as discussed below.

\section{NATIONAL IDENTITY AND THE “OTHER"}

Nationalist feelings have surfaced in the past at times when there has been a sense of threat from what is perceived as the outsider. On the one hand, discursive strategies of othering are instrumentalised to build a sense of national cohesion and belonging. On the other hand, national identity is constructed by in-group and out-group boundaries. These boundaries shift and change according to historic and societal contexts. The following sections present the main othering strategies that have taken place over the recent decades.

\section{Portugal AND Spain}

One cannot speak about Portugal's national identity without referring and comparing to that of Spain. The relationship between the two countries has been the subject of much debate relating to their identities, be they similar, different or parallel (Flynn, 2001; Sobral, 2003). Their overlapping histories have provided fruitful grounds for 
disagreement over finer points of national definition. Recognizing the two nations as parallel and complementary entities, $19^{\text {th }}$ century proposals for an Iberian federation, by Portuguese and Spanish intellectuals alike, emphasized the allied but different identities of the two nation-states (Flynn, 2001, p. 705).

Notwithstanding this view, there were recurrent suggestions that Portugal could be reclaimed as part of Spain in Spanish political circles in the 19th and early $20^{\text {th }}$ centuries (Flynn, 2001, p. 134). This did little in terms of assuring the Portuguese that all Spanish recognized the legitimacy of their statehood and its particular national identity, one which, unlike that of Spain, was not challenged by the development of alternative nationalisms. Even within similar sectors of the Spanish and Portuguese authoritarian right during the 2oth century, opinions diverged as to the legitimate relationship between the two nations, resulting in an overt distance in Spanish-Portuguese relations until the late 196os. This distrust of Spain would finally dissipate after both countries joined the European Union in 1986.

\section{Portugal, THE RETURNING MigRANTS AND THE NEW MIGRANTS}

The recent decades have witnessed mass migration from the former colonies and from rural to urban areas, thus producing new discourses of belonging. After the 1974 revolution, Portugal received 600.000 retornados (Portuguese citizens from its former colonies) increasing its population by around $5 \%$, at a moment in national history when serious political instability and a far-reaching economic crisis were felt. The latter were mostly second or third-generation emigrants from continental Portugal who had been born overseas and had never set foot in the European country itself'4. The group also included Angolans, Mozambicans, Cape Verdeans, etc., who held a Portuguese passport, and Timorese (after the 1976 Indonesian invasion of East-Timor), who also possessed a Portuguese passport. In parallel, Portuguese emigrants in Western Europe started to return to "their homeland" in order to settle down definitively. By the end of the 1990s and by the beginning of the twenty-first century, migrant-labourers first from Brazil and later from Eastern Europe (mainly Romania, Moldavia and Ukraine), arrive en masse in Portugal (Baganha, Marques \& Góis, 2004). Nonetheless, apart from references to the social and economic impact of the retornados, these other newcomers are only occasionally mentioned by experts in social studies, with the noteworthy exception of research in the field of migrant/minority studies. They are also usually omitted from the Presidential speeches delivered on National Day's. Therefore, it would appear that the construction and representation of national identity does not include a significant portion of the population.

\footnotetext{
14 There were also cases of first-generation retornados who had migrated to Africa in their early teens or twenties.

15 See, as an example, presidential speeches delivered on National Day, the 10th of June, by the former Presidents Jorge Sampaio and Anibal Cavaco Silva.
} 


\section{Portugal ANd Europe}

The issues arising from the relationship of differences and similarities between Portugal and other European countries (...) are controversial, although they have rarely been studied in a detached form. Portugal is a small country; geographically marginal and at the same time it is an old Nationstate whose identity and interests were built, to a certain degree, in contrast with continental Europe. (Cabral, 1992, p. 943)

This quotation aptly summarizes how the discursive construction of the country's identity has been represented. Its size and geographic location within Europe, the longlasting political state and the overseas colonies are the main recurrent topic. From the $19^{\text {th }}$ century onwards, Portugal's political independence was built and sustained through its territorial possessions. Politically, it was felt that, without the colonies, the country would not be powerful enough (or sufficiently large) to maintain its independence.

After the 1974 revolution, Portugal was confined to its European territory and the debate on national identity resumed. On the one hand, the end of the dictatorship facilitated the "opening to the world" and the questioning of the new/old national identity; on the other hand, the country had to readjust to a new political reality, in which Western Europe became the major political and economic partner. For political convenience, after 1974, the construction of Europe as the "other", both by Salazar and historiography, was rapidly reframed as "us". Simultaneously, former African colonies which had been the "us" of the Estado Novo, became an ambivalent "other" and "us" in post-revolutionary discourse, depending on national and international strategic motives.

The country had to resolve the tension between the European and the luso-tropical political outlooks. Colonization and emigration had been a part of the construction of national identity. Historically, the elites had persistently produced discourses on the symbolic meaning of the colonies. The recent and belated processes of democratization, decolonization and the joining of the European Union in 1986 forced new discourses and representations of what it meant to be Portuguese in relation to Europe and to the so-called "European challenge".

Apparently, differences between Portugal and Europe are not an issue (Cabral, 1992). In fact, various opinion polls from the 1990 do not highlight distinct differences in attitudes, values and behaviour. The distinction, rather, lies in the noticeable levels within the same parameters, revealing the belatedness of Portugal's democratic institutions, processes, and the heavily censored public sphere (see also Gil, 2004).

\section{Conclusion}

All aspects considered, one must remember that (national) identity construction is a fluid process. Amongst the manifold dimensions, national identity is realized "as a controlled distribution" (ledema \& Caldas-Coulthard, 2008, p. 6). As a result, we must ask who has access to the enactments on Portuguese national identity, who controls their distributions and what or who is placed in the background or omitted. For instance, the 
reiteration of the "imagined community" as a homogeneous society does not allow room for difference. Similarly, the hegemonic narrative on the "country's destiny", "the country's future" or the "country's opening to the world" (as opposed to the dictatorship's careful monitoring of any cross-border relationships) does not open the public sphere to different narratives.

This essay describes the most salient discourses on Portuguese national identity over the $19^{\text {th }}$ and $20^{\text {th }}$ centuries and four main arguments have been put forward. Firstly, contemporary historians and sociologists do not propose one single explanation of what Portuguese identity, character or traits, might be. Secondly, they base their claims mostly on historical processes, although they are careful to highlight the complexity and multi-variety of the phenomena. Thirdly, they note the divide between the elite minority - and their respective claims on the essence of Portugueseness - and the majority of the uneducated, "news un-savant" population. Fourthly, the access to the public sphere was seriously restricted by the Estado Novo ideology and its very specific devices to kerb the population's access to schooling and the inherent lack of social and economic upward mobility. Albeit for different reasons, one could claim that, to a certain extent, this is still the case. These restrictions reflect not only the population's lack of engagement with the political and symbolic power, but also the perception of social inequality and lack of plurality in various societal dimensions, which is common to contemporary neo-liberal societies.

Therefore, and to answer the questions presented at the beginning of this section about who has access to the enactments on and definition of Portuguese national identity and who controls this distribution, one could argue that the elite determine discourses on national identity and belonging, as well as who dominates the "banal flagging of nationhood" (Billig, 1995). Nevertheless, the perception of Portugal as a "strong symbolic identity" (Lourenço, 1997, p. 42) continues, and what apparently prevails in most contemporary narratives are recurrent collective memories of historical events, symbols and literary canonical writers.

In opposition, the ethno-symbolic view (Özkirimli, 2000), shared mostly by philosophers such as Almeida $(1995,2002)$, Gil (2004) and Lourenço $(1988,1997)$, contends that elites select elements with "meaning and significance for that particular population", mobilizing people who respond to calls for action that resonate through the use of meaningful symbols and myths based on pre-existing ethnic bonds (Skey, 2008, p. 29). However, in shifting attention to the cultural dimension of nationalism this perspective tends to essentialise ethnicity, by assigning "historically-significant myths, symbols, values and practices an important role to play in generating an image of the nation" (Skey, 2008, p. 29). As such, this view fails to assess how these national identity narratives are transformed over time in response to the various historic events (Skey, 2008, p. 30).

As we have seen, most narratives insist on the image of Portugal as a very homogeneous country, with a strong in-group discursive construction. Indeed, there even seems to be no room for counter-discourses. When compared, whilst other (national) contexts have witnessed the impact of ex-colonials, immigrants and asylum seekers in re-defining and eroding images of a homogenous national identity, these types of influxes have not 
had an impact on Portuguese discourses on national identity (neither in academic output nor in media or state official discourses). A recent example is that in 2015 , during the so called "migrant crisis", the Portuguese press was concerned with positive self-presentation of Portugal as a tolerant society, ready and able to engage in actions of support for and solidarity with those less fortunate than 'us' (Torkington \& Ribeiro, 2018).

Because national identity is based on selective remembering and selective forgetting, the forced absence of important historical facts in identity narratives to serve specific (state or elite) purposes has long been acknowledged, but this fact only enhances the need to critique these practices as they might involve various forms of opacity.

Nonetheless, and going back to Billig's words, "if nationalism is a wider ideology, whose familiar commonplaces catch us unawares (...) it is naive to think that a text of exposure can escape from the times and place of its formulation" (1995, p. 12), which means of course that this study is unavoidably embedded in its own layers of context.

\section{REFERENCES}

Ato Colonial 1930, de 8 de julho, República Portuguesa. Retrieved from https://www.parlamento.pt/ Parlamento/Documents/acto_colonial.pdf

Almeida, J. C. (2004). Portugal, o Atlântico e a Europa: a identidade nacional, a (re)imaginação da nação e a construção europeia. Nação e Defesa, 107, 147-172. Retrieved from http://www.idn.gov.pt/publicacoes/ consulta/NeD/NeD107/NeD107.pdf

Almeida, O. T. (1995). Em busca da clarificação do conceito de Identidade Cultural - o caso açoriano como cobaia. Paper presented at the Congresso do I Centenário da Autonomia dos Açores, Ponta Delgada.

Almeida, O. T. (2002). National identity - a revisitation of the Portuguese debate, NUI Maynooth papers in Spanish, Portuguese and Latin American Studies. NUI Maynooth.

Almeida, O. T. (2004). Onésimo Teotónio de Almeida: uma entrevista sobre o utopismo português no rescaldo de uma palestra sobre o conceito de identidade. E-topia: Revista Electrónica de Estudos sobre a Utopia, 1, 1-5 Retrieved from http://ler.letras.up.pt/uploads/ficheiros/artigo10481.PDF

Anderson, B. (1983/2006). Imagined communities: reflections on the origin and spread of nationalism. London \& New York: Verso.

Baganha, M., Marques, J.C. \& Góis, P. (2004). The unforeseen wave: Migration from Eastern Europe to Portugal. In M. Baganha \& M. L. Fonseca (Eds.), New waves of migration from Eastern to Southern Europe (pp. 23-40). Lisboa: Metropólis.

Barreto, A. (1994). Portugal, a Europa e a Democracia. Análise Social, 29 (129), 1051-1069. Retrieved from http://analisesocial.ics.ul.pt/documentos/1223378256M5dFA4xr9Oe65Q11.pdf

Barreto, A. (1995). Portugal na periferia do centro: mudança social, 1960 a 1995. Análise Social, 30 (134), 841855. Retrieved from http://analisesocial.ics.ul.pt/documentos/1223388784X1kPT5fa3Yr88TD2.pdf

Barreto, A. (2000). Portugal e a Europa: quatro décadas. In A situação social em Portugal 1960-1999 (Vol. 2, pp. 37-75). Lisboa: Imprensa de Ciências Sociais.

Barreto, A. \& Pontes, J. (writers) (2007). 04 Nós e os outros - uma sociedade Plural [TV]. In Rádio Televisão Portuguesa (Producer), Portugal, um retrato social, Portugal. 
Billig, M. (1995). Banal nationalism. London: Sage.

Biles, J. \& Spoonley, P. (2007). Introduction national identity: what it can tell us about inclusion and exclusion. National Identities, 9(3), 191-195. DOI: 10.1080/14608940701406146

Braga, T. (1894). A pátria portuguesa: o território e a raça. Porto: Livraria Chardron.

Braga, T. (1885/1995). O povo português nos seus costumes, crenças e tradições. Lisboa: Publicações Dom Quixote.

Cabral, M. V. (1992). Portugal e a Europa: diferenças e semelhanças. Análise Social, 27 (118-119), 943-954. Retrieved from http://analisesocial.ics.ul.pt/documentos/1223055416E2mQD7hf9Vw88HW7.pdf

Cabral, M. V. (1999). A sociedade portuguesa e a Revolução de Abril. Conference paper presented at the Lições de História Contemporânea, Universidade do Algarve.

Carvalho, M. \& Cabecinhas, R. (2013). The orthographic (dis)agreement and the Portuguese identity threat. Portuguese Literary Q Cultural Studies, 25, 82-95. Retrieved from http://hdl.handle.net/1822/2533525

Castelo, C. (1999). 'O modo português de estar no mundo': o luso-tropicalismo e a ideologia colonial portuguesa: 1933-1961. Porto: Edições Afrontamento.

Castelo, C. (2011). Uma incursão no lusotropicalismo de Gilberto Freyre. Blogue História Lusófona, 6, 261-280.

Conde, I. (1990). Identidade nacional e social dos jovens. Análise Social, 25 (108-109), 675-693. Retrieved from http://analisesocial.ics.ul.pt/documentos/1223034770Q7eVC8cc6Clo4LH5.pdf

Correia, A. A. M. (1919). Raça e nacionalidade. Porto: Renascença Portuguesa.

Cruzeiro, M. M. (2014). O 25 de Abril de 1974 memória da revolução e revolução da memória. Revista Lusófona de Estudos Culturais / Lusophone Journal of Cultural Studies, 2(1), 25-34. Retrieved from http:// www.rlec.pt/index.php/rlec/article/viewFile/53/46

Cunha, I.F. (2003). Imagens da imigração em Portugal. Media e Jornalismo, 2, 71-87.

Cunha, I.F. (2004). Imigração e racismo: dez anos nos media. Boca biblioteca on-line da Ciência e Comunicação. Retrieved from www.bocc.ubi.pt.

Cusack, I. (2005). Tiny transmitters of nationalist and colonial ideology: the postage stamps of Portugal and its Empire. Nations and Nationalism, 11(4), 591-612. DOI: 10.1111/j.1469-8129.2005.00221.x

De Cillia, R., Reisigl, M. \& Wodak, R. (1999). The discursive construction of national identity. Discourse and Society, 10(2), 149-173. DOI: 10.1177/0957926599010002002

Ferreira, J. M. (1993). Portugal em transe (1974-1985). In J. Mattoso (Ed.), História de Portugal (Vol. 8). Lisboa: Círculo de Leitores.

Flynn, M. K. (2001). Constructed identities and Iberia. Ethnic and Racial Studies, 24(5), 703-718. DOI: $10.1080 / 01419870120063945$

Freyre, G. (1942). Uma cultura ameaçada: a luso-brasileira. Rio de Janeiro: Casa do Estudante do Brasil.

Gellner, E. (2006/1983). Nations and nationalism. London: Blackwell Publishing.

Gil, J. (2004). Portugal, hoje: o medo de existir. Lisboa: Relógio D’Água.

Habermas, J. (1962/1991). The structural transformation of the public sphere. Cambridge, Mass.: MIT Press.

Herculano, A. (1846/1980-81). História de Portugal. Lisboa: Livraria Bertrand. 
ledema, R. \& Caldas-Coulthard, C. R. (2008). Introduction. In R. Idema \& C. R. Caldas-Coulthard (Eds.) Identity trouble: critical discourse and contested identities. New York: Palgrave, Macmillan.

Lourenço, E. (1988). Identidade e memória. In E. Lourenço (Ed.), Nós e a Europa ou as duas razões (pp. 9-23). Lisboa: Imprensa Nacional - Casa da Moeda.

Lourenço, E. (1997). 1900-2000: Portugal e os desafios finisseculares. In Pavilhão de Portugal Instituto de História Contemporânea, Universidade Nova de Lisboa (Ed.), Portugal na Transição do Milénio (pp. 3544). Lisboa: Fim de Século.

Lubkemann, S. C. (2002). The moral economy of Portuguese postcolonial return. Diaspora: a Journal of Transnational Studies, 11(2), 189-213. Project MUSE, DOI: 10.1353/dsp.2011.0041

Martins, G. de O. (2007). Portugal identidade e diferença. Lisboa: Gradiva.

Martins, J. P. O. (1879/1917). História de Portugal (Vol. I). Lisboa: Parceria António Maria Pereira.

Mattoso, J. (1998). A identidade nacional. Lisboa: Gradiva.

Medeiros, P. de (1996). Introdução: "em nome de Portugal”. Discursos: Estudos de Língua e Cultura Portuguesa, 13, 12-29.

Mónica, M. F. (1999). Trinta anos que mudaram Portugal. In M. F. Mónica (Ed.), Cenas da vida portuguesa (pp. 13-55). Lisboa: Quetzal.

Özkirimli, U. (2000). Theories of nationalism: a critical introduction. New York: Palgrave Macmillan.

Passos, S. (2016, January 6). "Retornados": os refugiados portugueses do século XX. [Weblog post]. Retrieved from https://euacuso.blogs.sapo.pt/retornados-os-refugiados-portugueses-do-311527

Peixoto, J. (2014). Portugal. In A. Triandafyllidou \& R. Gropas (Eds.), European immigration: a sourcebook (pp. 287-299). Farnham: Ashgate.

Reis, A. (Ed.) (1993). Portugal: 20 Anos de Democracia. Lisboa: Círculo de Leitores.

Ribeiro, F. P. (2009). The discursive construction of Portuguese national identity: elite vs. lay participants discursive strategies in a phone-in radio show. Papers from LAEL PG 2008, 3, 79-97. Retrieved from http://www.lancaster.ac.uk/fass/events/laelpgconference/papers/vo3/Ribeiro.pdf

Ribeiro, F. P. (2011). 'A democratic revolution must always remain unfinished': commemorating the Portuguese 1974 revolution in newspaper opinion texts. Journal of Language and Politics, 10(3), 372-395. DOI: $10.1075 /$ jlp.10.3.04rib

Ribeiro, M. C. (2003). Uma história de regressos: império, guerra colonial e pós-colonialismo. Oficina do Centro de Estudos Sociais, 188, 1-34.

Rosas, F. (2001). O Salazarismo e o homem novo: ensaio sobre o Estado Novo e a questão do totalitarismo. Análise Social, 35(157), 1031-1054. Retrieved from http://analisesocial.ics.ul.pt/documentos/1218725377D 6jFO4wy1Oi67NG6.pdf

Santos, B. S. (1993). Portugal: um retrato singular. Porto: Afrontamento.

Saraiva, A. J. \& Lopes, O. (1987). História da literatura portuguesa. Porto: Porto Editora.

Sidaway, J. D. \& Power, M. (2005). 'The tears of Portugal': empire, identity, 'race', and destiny in Portuguese geopolitical narratives. Environment and planning D: society and space, 23, 527-554. DOI: 10.1068/d345t 
Skey, M. (2008). Flagging nations? Exploring the banality of national discourse through a study of everyday talk and media texts in England. Unpublished PhD thesis, London School of Economics, London, United Kingdom.

Smith, A. D. (1998). Nationalism and modernism: a critical survey of recent theories of nations and nationalism. London: Routledge.

Sobral, J. M. (2004). O Norte, o Sul, a raça, a nação - representações da identidade nacional portuguesa (séculos XIX-XX). Análise Social, 39 (171), 255-284. Retrieved from http://analisesocial.ics.ul.pt/documen tos/1218705452QonRE7ep1Tg38Z)4.pdf

Sobral, J. M. (2003). A formação das nações e o nacionalismo: os paradigmas explicativos e o caso português. Análise Social, 37(165), 1093-1126. Retrieved from http://analisesocial.ics.ul.pt/documentos/1 218736434JoeQU4wx7Ro77GX9.pdf

Stråth, B. \& Wodak, R. (2009). Europe - discourse - politics - media - history: constructing 'crisis'? In A. Triandafyllidou, R. Wodak \& M. Krzyzanowski (Eds.), The European public sphere and the media: Europe in crisis (pp. 15-33). Basingstoke, New York: Palgrave Macmillan.

Torkington, K. \& Ribeiro, F.P. (2018). 'What are these people: migrants, immigrants, refugees?': migrationrelated terminology and representations in Portuguese digital press headlines. Discourse Context Media. Advance online publication. DOI: 10.1016/j.dcm.2018.03.002.

Vieira, R. \& Trindade, J. (2008). Migration, culture and identity in Portugal. Language and Intercultural Communication, 8, 36-49. DOI: 10.2167/laic266.0

Wodak, R. (2006). Discourse-analytic and socio-linguistic approaches to study of nation(alism). In G. Delanty \& K. Kumar (Eds.), The Sage handbook of nations and nationalism (pp. 104-117). London: Sage.

\section{BiOgRAPHICAL NOTE}

Filipa Perdigão Ribeiro is a Senior Lecturer at University of the Algarve, School of Management, Tourism and Hospitality (Portugal). She holds a PhD in Applied Linguistics, Lancaster University (UK). In 2002, she was invited to join the editorial board of Dos Algarves: a Multidisciplinary e-Journal, of which she was co-editor-in-chief (2006-2016), having co-edited a special issue on Languages, Literature and Tourism (2014). Her current research interests focus on links between language(s), discourse and tourism in their multiple facets, national identities and on academic writing. She has published papers on national identity (Journal of Language and Politics, 2011), on sense of place amongst tourists (International Journal of Culture, Tourism, and Hospitality Research, 2013) and on migration (Social Q Cultural Geography, 2017; Discourse, Context Q Media, 2018). She regularly reviews papers for several journals and scientific meetings and is a researcher of CiTUR - Centre for Tourism Research, Development and Innovation (Portugal).

Email: fperdig@ualg.pt

Universidade do Algarve - ESGHT, Campus da Penha - Estrada da Penha, 8006139 Faro, Portugal.

\section{* Submitted: 17.04 .2018 \\ * Accepted: 10.07.2018}

